\title{
Time-dependent changes in gene expression induced by secreted amyloid precursor protein-alpha in the rat hippocampus
}

Margaret M Ryan ${ }^{1,2,3^{*}}$, Gary P Morris ${ }^{1,3,5}$, Bruce G Mockett ${ }^{1,4}$, Katie Bourne ${ }^{1,3}$, Wickliffe C Abraham ${ }^{1,4}$, Warren P Tate ${ }^{1,3}$ and Joanna M Williams ${ }^{1,2}$

\begin{abstract}
Background: Differential processing of the amyloid precursor protein liberates either amyloid- $\beta$, a causative agent of Alzheimer's disease, or secreted amyloid precursor protein-alpha (SAPPa), which promotes neuroprotection, neurotrophism, neurogenesis and synaptic plasticity. The underlying molecular mechanisms recruited by sAPPa that underpin these considerable cellular effects are not well elucidated. As these effects are enduring, we hypothesised that regulation of gene expression may be of importance and examined temporally specific gene networks and pathways induced by sAPPa in rat hippocampal organotypic slice cultures. Slices were exposed to $1 \mathrm{nM}$ sAPPa or phosphate buffered saline for $15 \mathrm{~min}, 2 \mathrm{~h}$ or $24 \mathrm{~h}$ and sAPPa-associated gene expression profiles were produced for each time-point using Affymetrix Rat Gene 1.0 ST arrays (moderated $t$-test using Limma: $p<0.05$, and fold change \pm 1.15$)$.

Results: Treatment of organotypic hippocampal slice cultures with $1 \mathrm{nM}$ sAPPa induced temporally distinct gene expression profiles, including mRNA and microRNA associated with Alzheimer's disease. Having demonstrated that treatment with human recombinant SAPPa was protective against $N$-methyl D-aspartate-induced toxicity, we next explored the SAPPa-induced gene expression profiles. Ingenuity Pathway Analysis predicted that short-term exposure to sAPPa elicited a multi-level transcriptional response, including upregulation of immediate early gene transcription factors (AP-1, Egr1), modulation of the chromatin environment, and apparent activation of the constitutive transcription factors CREB and NF-KB. Importantly, dynamic regulation of NF-KB appears to be integral to the transcriptional response across all time-points. In contrast, medium and long exposure to SAPPa resulted in an overall downregulation of gene expression. While these results suggest commonality between SAPPa and our previously reported analysis of plasticity-related gene expression, we found little crossover between these datasets. The gene networks formed following medium and long exposure to sAPPa were associated with inflammatory response, apoptosis, neurogenesis and cell survival; functions likely to be the basis of the neuroprotective effects of sAPPa.
\end{abstract}

Conclusions: Our results demonstrate that sAPPa rapidly and persistently regulates gene expression in rat hippocampus. This regulation is multi-level, temporally specific and is likely to underpin the neuroprotective effects of SAPPa.

Keywords: Secreted amyloid precursor protein alpha, Hippocampus, Organotypic slice cultures, Microarray, Ingenuity pathway analysis, Neuroprotection, Immediate early genes, MicroRNA, NF-KB

\footnotetext{
* Correspondence: margaret.ryan@otago.ac.nz

'Brain Health Research Centre, University of Otago, PO Box 56, Dunedin

New Zealand

2Department of Anatomy, Otago School of Medical Sciences, PO Box 913,

Dunedin, New Zealand

Full list of author information is available at the end of the article
} 


\section{Background}

Amyloid precursor protein (APP) is the parent molecule of the neurotoxic amyloid- $\beta$, implicated in the aetiology of Alzheimer's disease. Amyloid- $\beta$ is generated by sequential cleavage of APP by $\beta$ and $\gamma$-secretases. However, the likely predominant route of APP processing is via $\alpha$-secretase $[1,2]$, which not only precludes amyloid- $\beta$ production but also generates secreted amyloid precursor protein alpha (sAP $\alpha)[3,4]$. This molecule interacts with the $\beta$-secretase, BACE1, and directly inhibits amyloid- $\beta$ production [5]. Furthermore, mounting evidence implicates SAPP $\alpha$ in a wide variety of neuronal processes. It has been shown to both protect against glutamate toxicity in rat hippocampal neurons in vitro and in rat models of traumatic brain injury in vivo [6,7] and promote neurite outgrowth in vitro [8,9]. Furthermore, sAPP $\alpha$ has recently been shown to not only direct human embryonic stem cells into neuronal precursor cells $[10,11]$, but to increase proliferation of neural precursor cells from the rat hippocampus in vitro, and promote their proliferation in the mouse hippocampus in vivo [12]. Additionally, sAPP $\alpha$ has been shown to enhance synaptic plasticity and restore memory deficits in rats and mice in vivo [13-16]. While a definitive cognate receptor for sAPP $\alpha$ has not yet been identified, sAPP $\alpha$ is known to activate intracellular signalling cascades in both neurons and glia and enhance synaptic protein synthesis in vitro [17-21]. As the reported physiological effects of $\mathrm{sAPP} \alpha$, are dependent on rapid and persistent alterations in gene expression, it is also likely that regulation of transcription is integral to the function of sAPP $\alpha$.

Recently, expression of the transcription factor Egr1 was shown to mediate sAPP $\alpha$ stimulated axonal outgrowth of primary neurons from mice in vitro [22], and SAPP $\alpha$ has previously been shown to induce the expression of several neuroprotective genes in mouse organotypic hippocampal slices [23]. This observation is particularly important as the hippocampus is a region vulnerable to the early neurodegenerative changes observed in Alzheimer's disease. Interestingly, however, sAPP $\alpha$ knock-in mice show significantly lower expression of the plasticity related genes Arc, Egr2 and Fos. Furthermore, in general, the gene expression profiles of APP knockout and sAPP $\alpha$ knock-in mice do not differ substantially [24], questioning the role of the $N$-terminal region of APP in regulation of gene expression. In light of these somewhat conflicting data we sought to determine whether the application of SAPP $\alpha$ to organotypic hippocampal slice cultures for up to $24 \mathrm{~h}$ alters gene expression, and if so, whether the gene networks or biological pathways identified reflected the known physiological roles of sAPP $\alpha$. We found that sAPP $\alpha$ rapidly enhances the transcription environment and alters subsequent gene expression in a manner that is likely to underpin the reported neuroprotective effects of $\operatorname{sAPP} \alpha$.

\section{Results}

sAPPa protects against $\mathrm{N}$-methyl D-aspartate toxicity

We have previously shown that purified human recombinant SAPP $\alpha$ produced in our laboratory [25] regulates protein synthesis [17], synaptic plasticity and memory [16], as well as neurogenesis [10]. However, prior to determining the effects of sAPP $\alpha$ on gene expression, we sought to extend our assessment of the functionality of recombinant SAPP $\alpha$. Accordingly, we tested whether sAPP $\alpha$ could protect against $N$-methyl-D-aspartate (NMDA)-induced excitotoxicity in hippocampal organotypic slice cultures.

Hippocampal organotypic slice cultures (representative slices, Figure 1A, B) were challenged with NMDA (30 $\mu \mathrm{M}$, $30 \mathrm{~min}$ ) and cell death was assessed by measurement of propidium iodide (PI) fluorescence $48 \mathrm{~h}$ later. In phosphate buffered saline (PBS)-treated control cultures, the tissue had low PI fluorescence across all hippocampal regions, indicating little cell death (Figure $1 \mathrm{C}$ ). In contrast, NMDA treatment caused significantly higher levels of PI fluorescence in Cornu Ammonis area 1 and 3 (CA1, CA3) and the inner and outer blades of the dentate gyrus (DG) relative to the PBS-treated control cultures ( $p=0.000001,1$-way ANOVA followed by a Bonferroni post-hoc test; Figure 1D, F), indicating induction of extensive cell death. Slices were incubated with $0.03,0.1,1,10 \mathrm{nM}$ sAPP $\alpha$ or PBS-control for $24 \mathrm{~h}$ prior to, and for $48 \mathrm{~h}$ following NMDA insult. Incubation with $1 \mathrm{nM}$ sAPP $\alpha$ resulted in a significant reduction in PI fluorescence in CA1 $(p=0.033)$ and the inner $(p=0.034)$ and outer blades $(p=0.0001)$ of the DG compared with NMDA treatment alone (Figure 1E, F), indicating a neuroprotective effect. No significant effects were detected following incubation with the other sAPP $\alpha+$ NMDA concentrations but sAPP $\alpha$ exposure trended towards a U-shaped dose-response curve (see Additional file 1: Figure S1). Together, these findings indicate that $1 \mathrm{nM}$ sAPP $\alpha$ increases cell survival following NMDA exposure. Although sAPP $\alpha$ has previously been shown to protect against glutamate toxicity [6], glutamate and NMDA may induce excitotoxicity by nonoverlapping signaling pathways [26], and so this study extends the known neuroprotective effects of sAPP $\alpha$ and validates the activity of SAPP $\alpha$ in our model system.

\section{Regulation of gene expression by sAPPa}

To investigate the temporal effects of sAPP $\alpha$ on the hippocampal transcriptome, hippocampal organotypic slice cultures were treated with $1 \mathrm{nM}$ sAPP $\alpha$ (the optimally neuroprotective concentration) or PBS for either $15 \mathrm{~min}$, $2 \mathrm{~h}$ or $24 \mathrm{~h}$ and expression profiling was performed with 

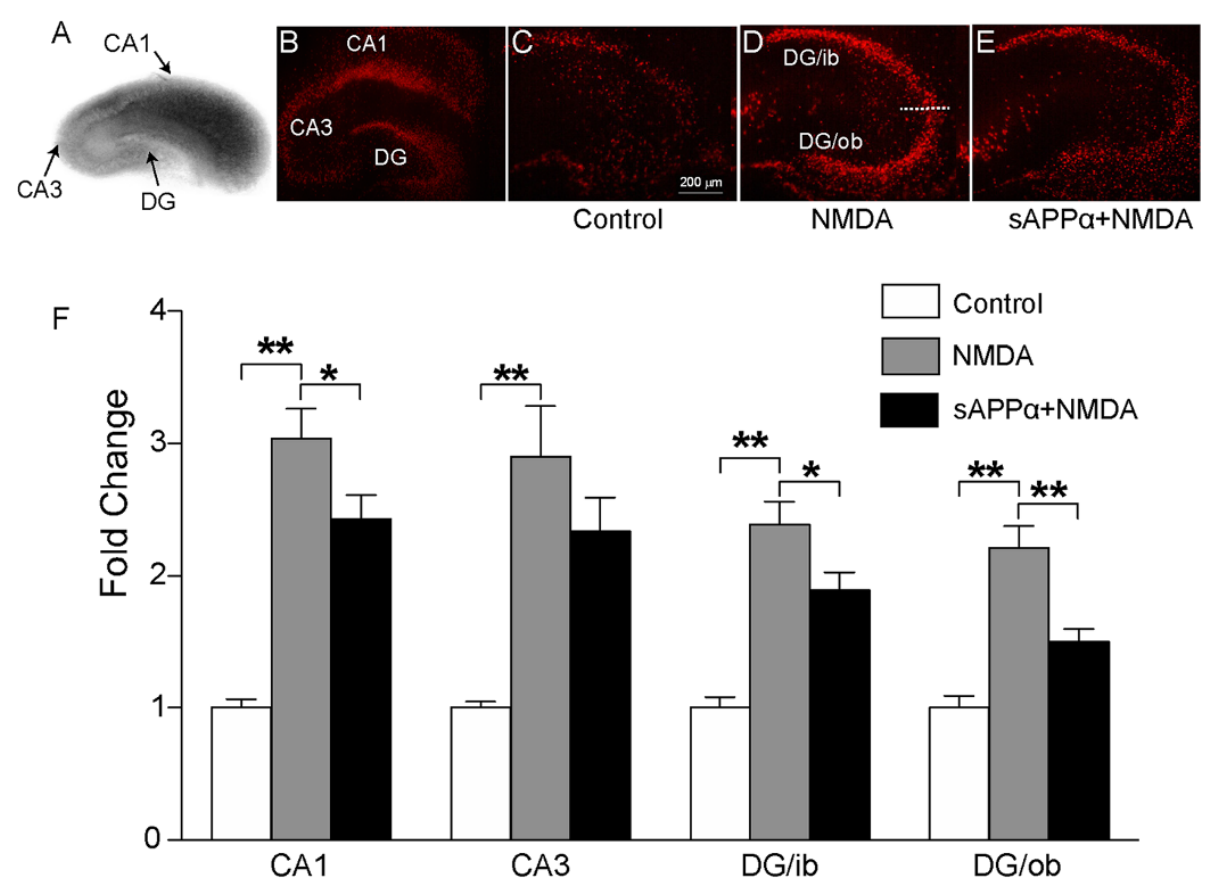

Figure 1 sAPPa protects organotypic hippocampal slices from excitotoxic cell death. (A) Representative brightfield image of a rat organotypic hippocampal slice. (B) Composite hippocampal slice showing high PI fluorescence, associated with total cell death in CA1 and CA3 and the dentate gyrus (DG) inner (ib) and outer blades (ob). Total cell death was induced by maintaining the slice at room temperature for $24 \mathrm{~h}$ in the absence of elevated $\mathrm{CO}_{2}$ levels. (C) Minimal PI fluorescence in the DG of a PBS-treated control slice. (D) Widespread PI fluorescence in the DG $48 \mathrm{~h}$ after NMDA challenge. (E) Reduced PI fluorescence in the DG following treatment with SAPPa and NMDA. (F) Regional analysis of PI fluorescence in organotypic hippocampal slices. Fold change: NMDA or NMDA + SAPPa PI fluorescence relative to PBS-treated control. NMDA treatment resulted in a $>2$ fold increase in PI fluorescence across all regions compared to PBS-control treated slices. Co-incubation with sAPPa and NMDA significantly reduced PI fluorescence in the CA1, DG/ib and DG/ob compared to NMDA alone. 1-way ANOVA with a Bonferroni posthoc test: ${ }^{*} p<0.05,{ }^{* *} p<0.01, \mathrm{n}=4$ animals, 19 slices/group.

Affymetrix Rat Gene 1.0 ST arrays ( $\mathrm{n}=5$ per condition). Data analysis, using dual selection criteria (moderated $t$-test, $p<0.05$ (Limma) and fold change \pm 1.15 ), identified temporally distinct sAPP $\alpha$-induced patterns of expression (Figure 2A), a subset of which was confirmed by quantitative PCR (qPCR; Figure 3 and see Additional file 2:
Tables S1-S4). The majority of genes were modestly changed (fold change: -2.9 to 3.2), an effect particular to neurobiological tissue [27] and consistent with previous studies [24,28-30]. Interestingly, two thirds (66\%) of differentially expressed genes were upregulated in the 15 min dataset, while the majority of differentially
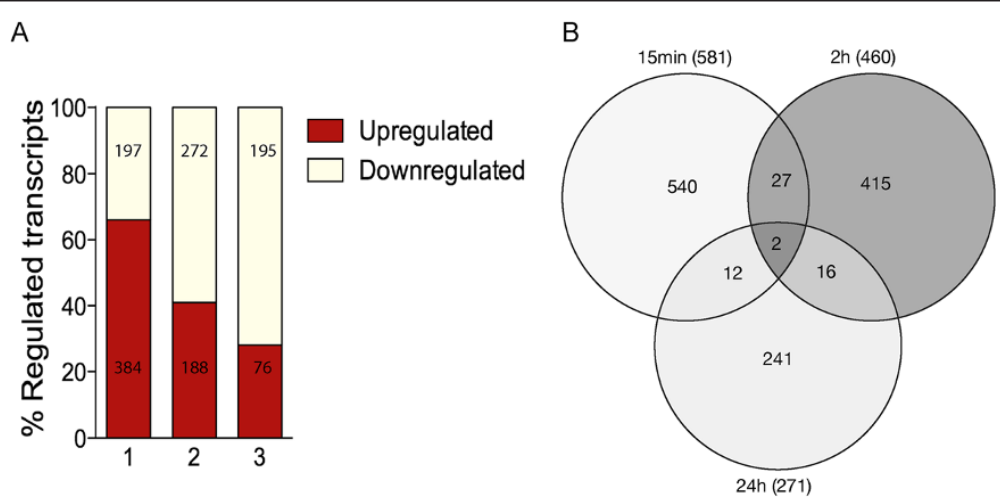

Figure 2 sAPPa regulates gene expression in a temporally specific manner. (A) Histogram showing that the majority of genes identified as differentially expressed following exposure of organotypic hippocampal slice cultures to sAPPa were upregulated at 15 min, while the majority were downregulated at $2 \mathrm{~h}$ and $24 \mathrm{~h}$. Differentially expressed genes were identified using a dual selection criteria $( \pm 1.15$ fold change; $p<0.05$ ), see text for further details. (B) Venn diagram showing that the three datasets involved distinct gene sets. 


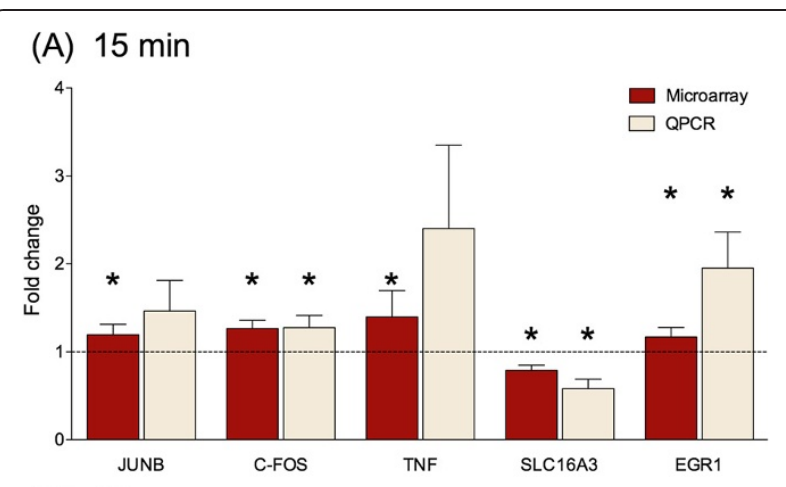

(B) $2 \mathrm{~h}$

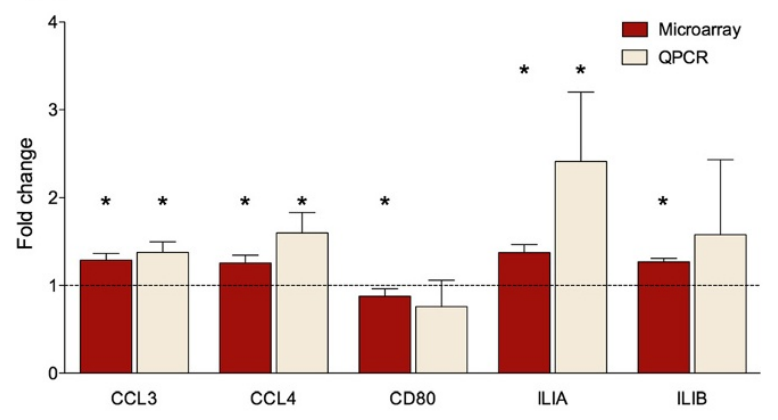

(C) $24 \mathrm{~h}$

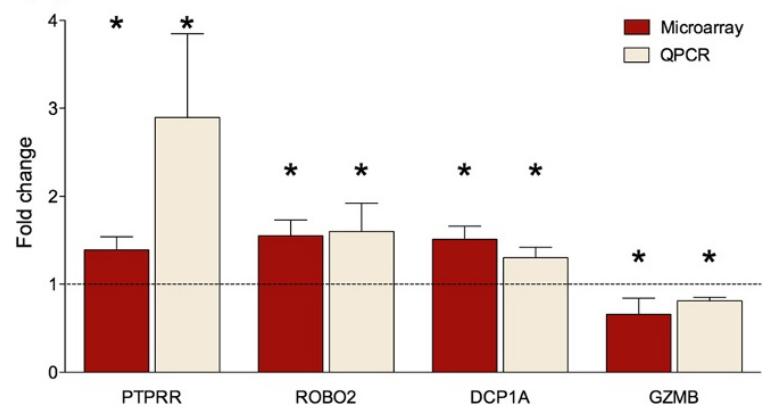

Figure 3 Validation of selected differentially expressed genes by qPCR. Microarray and corresponding qPCR results for (A) $15 \mathrm{~min}$ (B) $2 \mathrm{~h} \mathrm{(C)} 24 \mathrm{~h}$. Results are expressed as mean fold change +/- SEM and normalised to the housekeeping genes HPRT or PPIA using the $2^{-\Delta \Delta} C T$ method; $n=5$ per group. Significance was assessed using 1 tailed Student's t-tests: ${ }^{*} p<0.05$.

expressed genes were downregulated at $2 \mathrm{~h}$ (59\%) and $24 \mathrm{~h}(79 \%)$ (Figure 2A), suggesting that there is a relatively rapid onset homeostatic control of gene expression. Overall, these data confirm that $\mathrm{SAPP} \alpha$, the $N$-terminal region of APP, regulates gene expression in a time-dependent manner.

To explore further how the effects of sAPP $\alpha$ on gene expression changed with time, the expression profiles were examined using a Venn diagram. This analysis showed that the three datasets were largely distinct (Figure 2B; See Additional file 3: Table S5). Only two genes were in common across all three datasets and only one was annotated. Interestingly, this gene, acyl-protein thioesterase 2, (Apt2) showed a distinct temporal response to SAPP $\alpha$ treatment, decreasing in expression at $15 \mathrm{~min}(-1.25$ fold), increasing at $2 \mathrm{~h}(+1.4$ fold $)$ and decreased by $24 \mathrm{~h}(-1.8$ fold $)$. Activation of APT2 results in depalmitoylation of substrate proteins, a process important in regulating subcellular localisation of plasticity related ion channels and GAP43 $[31,32]$. Thus, these data predict that regulation of Apt2 contributes to the plasticity-related effects of sAPP $\alpha$.

As sAPP $\alpha$ enhances synaptic plasticity and restores memory deficits [13-16], we next investigated whether there was a significant crossover between our sAPP $\alpha-$ regulated datasets and those regulated by synaptic plasticity. Previously, we identified distinct patterns of gene expression elicited by hippocampal long-term potentiation (LTP), a widely accepted model of memory mechanisms and synaptic plasticity $[29,30]$. Here, we show that there was little intersection between the genes within the datasets (Table 1). For example, there were only five rapidly responding genes in common across the early time-points analysed (Table 1) and the fold change in these overlapping genes was relatively curtailed in the sAPP $\alpha$ dataset (Table 1). Despite this, when we compared biological functions and pathways between the two data sets, we found that they contained overlapping functions related to Gene Expression (20 min LTP and $15 \mathrm{~min}$ sAPP $\alpha$ ), Development (20 min LTP and $24 \mathrm{~h}$ sAPP $\alpha$ ) and Neurogenesis ( $5 \mathrm{~h}$ LTP and $24 \mathrm{~h}$ sAPP $\alpha$ ). This suggests that while there was little overlap in the actual genes regulated, there is overlap in some of the biological functions controlled by SAPP $\alpha$ and LTP.

As we found that $\mathrm{SAPP} \alpha$-induced a rapid upregulation followed by a generalised downregulation of gene expression, we hypothesised that this temporal pattern may be regulated by microRNA. A subset of probes on the Affymetrix Rat Gene 1.0 ST arrays represent stem loop microRNA sequences and therefore allow analysis of primary and precursor microRNA. We found evidence for regulation of 14 microRNA in response to sAPP $\alpha$ (Table 2), the majority of which were upregulated at $15 \mathrm{~min}$, suggesting that the mature microRNA may contribute to the later observed downregulation of gene expression. In accordance with this, we found no evidence for regulation by microRNA within the $15 \mathrm{~min}$ dataset using the web application miRvestigator Framework [33]. However, analysis of the $2 \mathrm{~h}$ dataset identified miR-154 $(p=4.7 \mathrm{e}-04)$ as a candidate microRNA controlling the expression of a subset of mRNA (Table 3). As the miR-154 primary transcript was increased at $15 \mathrm{~min}$ (Table 2) this suggests a role for miR-154 in sAPP $\alpha$ mediated gene expression, via mRNA degradation. Furthermore, miRvestigator predicted regulation by miR-201* $(p=2.4 \mathrm{e}-04)$ within the $24 \mathrm{~h}$ dataset (Table 3), although we found no evidence for altered levels of the primary microRNA transcript in our analyses. 


\begin{tabular}{|c|c|c|c|}
\hline \multirow{2}{*}{$\begin{array}{l}\text { Gene } \\
\text { symbol }\end{array}$} & \multirow[t]{2}{*}{ Gene title } & \multicolumn{2}{|c|}{ Fold change } \\
\hline & & $\begin{array}{l}15 \mathrm{~min} \\
\mathrm{sAPPa}\end{array}$ & $\begin{array}{l}20 \min \\
\text { LTP }\end{array}$ \\
\hline Dusp1 & Dual specificity phosphatase 1 & 1.2 & 3.9 \\
\hline Egr1 & Early growth response 1 & 1.2 & 4.2 \\
\hline JunB & Jun B proto-oncogene & 1.2 & 6.6 \\
\hline Rbp3 & retinol binding protein 3 , interstitial & 1.2 & 1.2 \\
\hline \multirow[t]{2}{*}{ Fos } & FBJ osteosarcoma oncogene & 1.2 & 9.7 \\
\hline & & $\begin{array}{l}2 \mathrm{~h} \\
\text { sAPPa }\end{array}$ & $\begin{array}{l}5 \mathrm{~h} \\
\text { LTP }\end{array}$ \\
\hline \multirow[t]{2}{*}{ Grasp } & GRP1 (general receptor for & 1.2 & 1.3 \\
\hline & & $\begin{array}{l}24 \mathrm{~h} \\
\text { sAPPa }\end{array}$ & $\begin{array}{l}24 \mathrm{~h} \\
\text { LTP }\end{array}$ \\
\hline Aox1 & Aldehyde oxidase 1 & 1.8 & 1.3 \\
\hline Bhmt2 & $\begin{array}{l}\text { Betaine-homocysteine } \\
\text { methyltransferase } 2\end{array}$ & -1.4 & -1.7 \\
\hline Elov6 & $\begin{array}{l}\text { ELOVL family member } 6 \text {, } \\
\text { elongation of long chain fatty acids }\end{array}$ & 1.3 & -1.3 \\
\hline
\end{tabular}

As production of the Alzheimer's disease-related amyloid- $\beta$ and SAPP $\alpha$ are mutually exclusive, we analysed how Alzheimer's disease-associated genes were affected in our three data sets. To achieve this we compared our datasets with the Alzheimer gene database, AlzGene [34] and carried out an in-depth literature search. We identified a group of mRNA and microRNA previously

Table 2 Temporally specific regulation of microRNA by sAPPa

\begin{tabular}{cccc}
\hline MicroRNA & \multicolumn{3}{c}{ Fold change } \\
\cline { 2 - 4 } & $\mathbf{1 5} \mathbf{~} \mathbf{m i n}$ & $\mathbf{2 ~ h}$ & $\mathbf{2 4} \mathbf{~ h}$ \\
\hline mir-9 & 1.3 & -1.2 & - \\
mir-27 & 1.2 & - & - \\
mir-29 & 1.3 & - & - \\
mir-30 & 1.2 & - & - \\
mir-130 & 1.2 & - & - \\
mir-135 & 1.3 & - & - \\
mir-154 & 1.2 & - & - \\
mir-204 & - & - & -1.7 \\
mir-218 & 1.2 & - & - \\
mir-219 & - & 1.2 & - \\
mir-299 & 1.2 & - & - \\
mir-505 & - & 1.2 & - \\
mir-544 & 1.2 & - & - \\
mir-592 & 1.2 & - & - \\
\hline
\end{tabular}

associated with amyloid- $ß$ induced toxicity (e.g. Frp2 and Ppif), or implicated in Alzheimer's disease processes, (miR-29 and miR-9) [35-47], (Table 4). As the expression of these genes was opposite to that observed in Alzheimer's disease this analysis suggests that SAPP $\alpha$ may act, in part, through the same pathways as amyloid- $\beta$.

\section{SAPPa rapidly regulates transcriptional processes}

To systematically investigate the functional significance of the genes rapidly regulated by SAPP $\alpha$, we used the Ingenuity Pathway Analysis (IPA) software to identify gene networks from the $15 \mathrm{~min}$ dataset. Gene expression was identified as the most significant biological function of the highest scoring network, with the majority of the genes in this network upregulated (Figure 4A; score 34). Analysis of this network showed multiple mechanisms engaged by sAP $\alpha$ to upregulate gene expression. This includes inducible transcription factors of the AP-1 complex [48] (FOS, JUNB and JUND) and the early growth response transcription factor, EGR1. Enhanced expression of Fos and Egr1 was confirmed by qPCR (Figure 3; Additional file 2: Table S4.); furthermore, the upstream regulatory analysis tool within IPA predicted downregulation of a negative regulator of AP-1 activity Fosl1/Fra1 (FOS-like antigen 1) $[49,50]$, an effect likely to further amplify the sAPP $\alpha$-induced transcriptional response (Figure 5A).

This network also predicts that sAPP $\alpha$ mediates transcription via activation of the plasticity-related transcription factors, cAMP response element binding protein (CREB) and nuclear factor kappa B (NF-kB), that form central hubs within the network. While their expression levels remain unchanged, this is highly consistent with their roles as constitutive transcription factors regulated by post-transcriptional modification. Indeed, this network includes Dusp1 (+1.2 fold), a plasticity-related phosphatase and Map3k14 (+1.2 fold), a kinase known to phosphorylate and activate NF- $\mathrm{kB}$, as well as the NF- $\mathrm{kB}$ regulatory molecule, $N f$-кbid $(+1.2$ fold) $[51,52]$. Together these data suggest that SAPP $\alpha$ treatment not only enhances the levels of transcription factors but also contributes to a dynamic interplay between a subset of protein kinases and phosphatases likely to maintain transcriptional activity.

Regulation of the chromatin environment is a third predicted mechanism by which SAPP $\alpha$ regulates expression of genes in this network. The network contains mediators of chromatin condensation (Kat2b: K(lysine) acetyltransferase; +1.2 fold) and histone biotinylation (Hlcs: holocarboxylase synthetase (biotin-(proprionylCoA-carboxylase (ATP-hydrolysing)) ligase; +1.2 fold) $[53,54]$. Upregulation of KAT2B is likely to result in reduced condensation of chromatin, occurring via acetylation of TNP2 (nuclear transition protein 2) a molecule also regulated within this network. 
Table 3 Predicted microRNA-regulated genes following miRvestigator Framework Analysis

\begin{tabular}{|c|c|c|c|c|}
\hline Predicted miR-154 regulated genes & Gene title & Transcript cluster ID & Fold change & $P$. Value \\
\hline Cks2 & CDC28 protein kinase regulatory subunit 2 & 10797559 & -1.18 & $2.11 \mathrm{E}-02$ \\
\hline Crygd & Crystallin, gamma D & 10928549 & -1.17 & 4.33E-02 \\
\hline Dapp 1 & Dual adaptor of phosphotyrosine and 3-phosphoinositides & 10826985 & -1.18 & $5.54 \mathrm{E}-03$ \\
\hline Hspa8 & Heat shock $70 \mathrm{kDa}$ protein 8 & 10826604 & -1.18 & $6.75 \mathrm{E}-03$ \\
\hline Luzp 1 & Leucine zipper protein 1 & 10880685 & 1.15 & 3.83E-02 \\
\hline Olr1014 & Olfactory receptor 1014 & 10893397 & -1.17 & 5.47E-03 \\
\hline Olr1106 & Olfactory receptor 1106 & 10906853 & -1.17 & 4.04E-02 \\
\hline Olr1560 & Olfactory receptor 1560 & 10750649 & -1.20 & 3.44E-02 \\
\hline Olr1679 & Olfactory receptor 1679 & 10830769 & -1.15 & 3.47E-03 \\
\hline Olr75 & Olfactory receptor 75 & 10709401 & -1.19 & 2.45E-02 \\
\hline Olr862 & Olfactory receptor 862 & 10879329 & 1.22 & $1.45 \mathrm{E}-02$ \\
\hline Polr3G & Polymerase (RNA) III (DNA directed) polypeptide G (32kD) & 10718152 & 1.18 & 1.46E-02 \\
\hline Rgd1309139 & Similar to CG5435-PA & 10818370 & -1.15 & 4.43E-02 \\
\hline Loc303448 & Similar to glyceraldehyde-3-phosphate dehydrogenase & 10715252 & -1.15 & $3.41 \mathrm{E}-02$ \\
\hline SIC5A7 & Solute carrier family 5 (choline transporter), member 7 & 10921208 & -1.19 & 2.23E-02 \\
\hline St18 & Suppression of tumorigenicity 18 & 10875154 & -1.21 & $1.98 \mathrm{E}-02$ \\
\hline Predicted miR-201* regulated genes & Gene title & Transcript cluster ID & Fold change & $P$. value \\
\hline Olr139 & Olfactory receptor 139 & 10709469 & -1.43 & $2.61 \mathrm{E}-02$ \\
\hline Olr1532 & Olfactory receptor 1532 & 10750614 & -1.72 & 4.48E-02 \\
\hline Rpl36Al & Ribosomal protein L36a-like & 10829826 & -1.36 & 4.34E-02 \\
\hline Rplp2 & Ribosomal protein, large, P2 & 10762590 & -1.43 & 3.70E-02 \\
\hline Rgd1307947 & Similar to RIKEN cDNA C430008C19 & 10822064 & -1.46 & 2.97E-02 \\
\hline WwC2 & WW and C2 domain containing 2 & 10788101 & 1.42 & 4.01E-02 \\
\hline
\end{tabular}

To further explore the $15 \mathrm{~min}$ dataset we used the functional annotation tool, DAVID. This highlighted Cognition and Sensory perception (Enrichment Score 2.2) as well as Response to corticosterone (Enrichment Scores $1.77,1.34$ ) as significantly enriched functions (Additional file 4: Table S6). Interestingly, there is an increase in basal glucocorticoid levels in Alzheimer's disease, [55,56]. Thus sAPP $\alpha$ may regulate the expression of genes associated with this pathway.

\section{sAPPa-induced regulation of apoptosis and the inflammatory response}

We next explored the gene networks affected by exposure to sAPP $\alpha$ for extended times. Following $2 \mathrm{~h}$ exposure to sAPPa, Inflammatory Response was the most significant biological function of the highest scoring network formed used IPA (Figure 4B; score 26). This network contains the proinflammatory cytokine $I l 1 a$, previously associated with Alzheimer's disease, development and plasticity [57-61], immune associated genes (Cd80, Cr2, Cd27, Dapp1) and chemokines $(\mathrm{Ccl} 3, \mathrm{Ccl} 4, \mathrm{Ccl} 21)$. These chemokines are involved in chemoattraction of immune cells to sites of tissue damage but have widespread non-immunological effects in the central nervous system, including regulation of neural cell proliferation, migration, survival and synaptic transmission $[62,63]$. That sAPP $\alpha$ treatment promotes regulation of chemokine responses is also supported from analysis of the $2 \mathrm{~h}$ data set with the functional annotation tool, DAVID (Additional file 4: Table S6).

Like the 15 min network, NF-kB forms a central hub in this network, however, many of the genes contributing to the hub, including Ehf (ets homologous factor), which promotes apoptosis [64], are downregulated. Interestingly, using the upstream regulatory element analysis tool to analyse the genes upregulated within the $2 \mathrm{~h}$ dataset, it is predicted that sAPP $\alpha$ induces inhibition of the transcription factor, tumour protein 53 (p53), which is also an important regulator of apoptosis, and is increased in Alzheimer's disease $[65,66]$ (Figure 5B). In addition, upstream regulatory element analysis using the entire $2 \mathrm{~h}$ dataset, predicts activation of the transcription factors AP-1, HMGB1 (high mobility group box protein) and STAT3 (signal transducer and activator of transcription 3) (Figure 5C) suggesting other mechanisms by which sAPP $\alpha$ coordinates this gene response. 
Table 4 sAPPa regulates genes linked to amyloid- $B$ toxicity and Alzheimer's disease

\begin{tabular}{|c|c|c|c|c|c|c|}
\hline \multirow[t]{2}{*}{ Gene symbol } & \multirow[t]{2}{*}{ Gene title } & \multicolumn{3}{|c|}{ Fold change } & \multirow[t]{2}{*}{ Functional effects } & \multirow[t]{2}{*}{ References } \\
\hline & & $15 \mathrm{~min}$ & $2 \mathrm{~h}$ & $24 \mathrm{~h}$ & & \\
\hline Fish & Adapter protein TKS5 & 1.2 & - & - & Mediates the neurotoxic effect of amyloid- $\beta$ & [35] \\
\hline Frp2 & Formyl peptide receptor 2 & - & - & -1.4 & $\begin{array}{l}\text { Activated by amyloid- } \beta \text {, may mediate inflammation } \\
\text { seen in Alzheimer's disease }\end{array}$ & [36] \\
\hline Gapdh & $\begin{array}{l}\text { Glyceraldehyde-3-phosphate } \\
\text { dehydrogenase }\end{array}$ & 1.2 & - & -1.5 & $\begin{array}{l}\text { May interact with neurodegenerative disease- } \\
\text { associated proteins }\end{array}$ & [37] \\
\hline Ppif & Peptidylprolyl isomerase $\mathrm{F}$ & - & - & -1.4 & $\begin{array}{l}\text { An absence of this gene is neuroprotective against } \\
\text { amyloid- } \beta \text { induced cell death }\end{array}$ & [38] \\
\hline $\operatorname{Tnf}$ & Tumour necrosis factor & 1.4 & - & - & Protects neurons against amyloid- $\beta$ induced toxicity & [39] \\
\hline Ttr & Transthyretin & - & -2.8 & - & Binds amyloid- $\beta$ and prevents fibril formation in vitro & [40] \\
\hline $\mathrm{CCl}-3$ & Chemokine (C-C motif) ligand 3 & - & 1.3 & - & Protein levels are increased in Alzheimer's disease & [41] \\
\hline Fos & $\begin{array}{l}\text { FBJ murine osteosarcoma viral } \\
\text { oncogene homolog }\end{array}$ & 1.3 & - & - & Gene expression is increased in Alzheimer's disease & [42] \\
\hline$\| l i b$ & Interleulin 1-beta & - & 1.3 & - & Protein levels are increased in Alzheimer's disease & [43] \\
\hline MiR-9 & MicroRNA- 9 & 1.2 & -1.2 & - & Expression is reduced in Alzheimer's disease & [44] \\
\hline MiR-29 & MicroRNA-29 & 1.3 & - & - & $\begin{array}{l}\text { Regulator of BACE1 and decreased in Alzheimer's } \\
\text { disease }\end{array}$ & [45] \\
\hline Otc & Ornithine transcarbamylase & -1.2 & - & - & Gene expression is increased in Alzheimer's disease & [46] \\
\hline Rgs/2 & $\begin{array}{l}\text { Regulator of G-protein signaling } \\
\text { like } 2\end{array}$ & - & 1.2 & - & Gene associated with late onset Alzheimer's disease & [47] \\
\hline
\end{tabular}

\section{sAPPa-induced long-term regulation of neurogenic,} inflammatory response and cell survival pathways

As the reported biological functions of sAPP $\alpha$, such as neuroprotection and regulation of memory, are enduring physiological changes, we explored the gene expression response induced by a $24 \mathrm{~h}$ exposure to sAPP $\alpha$. To identify the functional relationships within the $24 \mathrm{~h}$ differentially expressed gene list, we used the DAVID functional annotation tool. This analysis identified Neurogenesis, Morphogenesis and Development as important biological functions affected $24 \mathrm{~h}$ post-sAPP $\alpha$ treatment (Enrichment Scores 2.26-1.48) (Additional file 4: Table S6, See Additional file 5: Figure S2).

We extended analysis of this dataset by interpretation of the highest scoring network derived using IPA, (Figure 4C). This network was composed of genes with overlapping biological functions, including upregulated genes related to cell proliferation (Cd80, Ubn1, Ptprr; validated by qPCR; Figure 3; Additional file 2: Table S4), regulation of genes likely to promote cell survival (Inkb1, Cd80, Sgk1, Fpr2, Cxcr4) and inhibit apoptosis $(G z m b$; validated by qPCR; Figure 3 ; Cxcr4, Ifnb1, Sgk1). As sAPP $\alpha$ has previously been shown to promote growth, survival and proliferation in neurons and stem cells $[10,67,68]$ these findings supports a role for sAPP $\alpha$-induced gene expression in mediating these events.

\section{Discussion}

In order to better understand the role that regulation of gene expression may play in mediating the wide-ranging cellular effects of sAPP $\alpha$, we performed a global transcriptome analysis in organotypic hippocampal slice cultures treated with $1 \mathrm{nM}$ sAPP $\alpha$ for $15 \mathrm{~min}, 2 \mathrm{~h}$ or $24 \mathrm{~h}$. We focused on the hippocampus as this region is essential to learning and memory and is especially vulnerable to degeneration in Alzheimer's disease [69]. Our analysis demonstrated that $\mathrm{SAPP} \alpha$ rapidly regulates gene expression by engaging multiple transcriptional regulatory mechanisms. This is evidenced by rapid and transient upregulation of inducible transcription factors (AP-1 complex, EGR1), temporally specific regulation of constitutively expressed transcription factors (NF-kB, CREB) and microRNA, as well as, modulation of the chromatin environment.

Network analysis showed that regulation of NF- $\mathrm{kB}$ is a consistent theme across all three time-points investigated. This supports previous work proposing that the neuroprotective effects of sAPP $\alpha$ are mediated through activation of NF- $\mathrm{kB}$ and subsequent enhanced activation of gene expression [70,71]. sAPP $\alpha$-induced NF- $\mathrm{B}$ activation is implicated in protecting neural cells from apoptosis, therefore our results suggest a role for specifically regulated genes in this process [72]. Interestingly, NF- $\mathrm{kB}$ has recently been intimately linked with amyloid- $\beta$ production $[73,74]$ and sAPP $\alpha$ modulates APP processing [5]. Therefore, the control of amyloid- $\beta$ production may be crucially dependent on the activation status of NF- $\kappa B$, over which sAPP $\alpha$ has influence [70-72].

Increasing evidence points to the involvement of dysregulated microRNA in Alzheimer's disease [75] and 


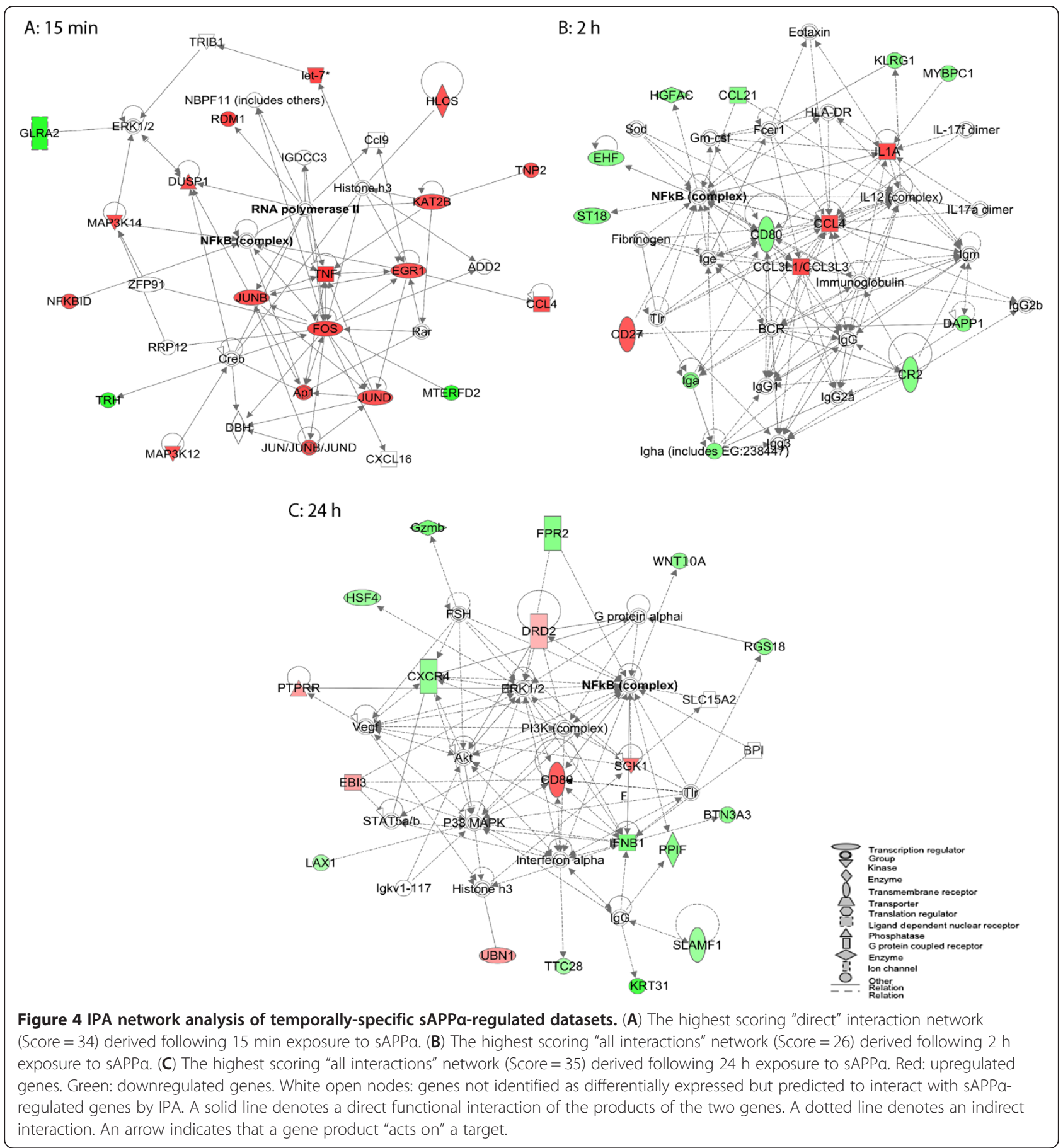

indeed an NF-kB-sensitive microRNA has been implicated in modulating the inflammatory circuit in Alzheimer's disease [76]. Our results highlight a role for microRNA in sAPP $\alpha$-induced regulation of gene expression. We found that a short-term exposure to SAPP $\alpha$ was associated with upregulation of a subset of microRNA. As medium to long-term sAPP $\alpha$ exposure resulted in a general decrease in gene expression, we propose that this may be mediated by microRNA. Interestingly, we reported a similar general effect on gene expression following the induction of LTP, which we have shown to be associated with altered levels of mature microRNA [30]. Our results also demonstrate that sAPP $\alpha$ induces a subset of plasticity-associated immediate early genes, however, we found little evidence that the sAPP $\alpha$-induced gene response paralleled that of the LTP gene response. Therefore, post-translational modifications, and altered synaptic protein synthesis, 


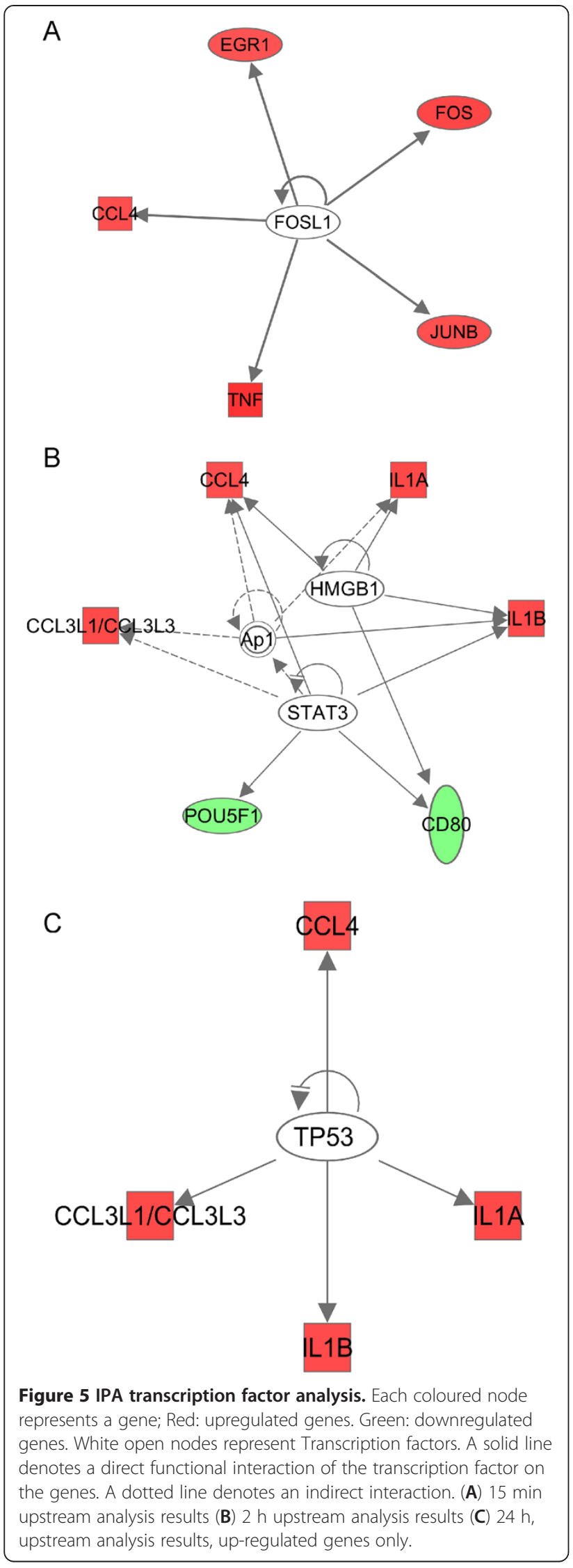

are likely to mediate many of the effects of sAPP $\alpha$ on LTP $[17,77,78]$.

It is of particular note that prolonged exposure to sAPP $\alpha$ resulted in persistent effects on gene expression that correlate closely with the documented neuroprotective and neurogenic roles of sAPP $\alpha$. This interpretation is consistent with the only other microarray analysis of sAPP $\alpha$-regulated gene expression in the hippocampus [23]. This study reported that treatment of mouse organotypic slices with $1 \mathrm{nM}$ sAPP $\alpha$ for $24 \mathrm{~h}$ also resulted in regulation of several neuroprotective genes. Interestingly, there was little coherence between the genes identified in this study and our own. This may result from differences in the array type used (Affymetrix MG-U74Av2 vs. Rat Gene 1.0 ST), the number of annotated genes investigated $(\sim 9,000 \mathrm{vs} \sim 28,000)$, the statistical analyses performed (Wilcoxon signed rank test vs. moderate paired $t$-test) or species (mouse vs. rat).

While there is a paucity of data estimating the physiological levels of sAPP $\alpha$, it has been estimated to fall within the $\mathrm{pM}$ range within plasma and brain homogenates [79-81], however, it is difficult to extrapolate these concentrations to the ex vivo model used in this study. Our studies highlight that $1 \mathrm{nM} \mathrm{sAPP \alpha}$ is sufficient to modulate gene expression in ex vivo models and emphasizes that both medium and longer-term exposure to SAPP $\alpha$ elicits an inflammatory and immune gene response, which likely provides a neuroprotective environment. This neuroprotective setting appears to be strengthened by a parallel downregulation of apoptotic pathways and increases in cell proliferation and survival. Furthermore, we found evidence for the regulation of genes associated with neurogenesis. Recent evidence has also linked sAPP $\alpha$ with the induction of neurogenesis in the mammalian brain [10-12,82]. As new brain cells have the capacity to integrate into previously established neural networks and contribute to hippocampal functioning [83], neurogenesis may also contribute to the sAPP $\alpha$-induced neuroprotective and memory enhancing effects over the long-term.

\section{Conclusion}

In summary, our analyses consolidate the concept that sAPP $\alpha$ regulates gene expression. We provide evidence that this occurs in a temporally specific manner, and occurs through providing an environment conducive for transcription that results in activation of immediate early gene transcription factors, known to mediate neuroprotection and proliferation $[84,85]$, and regulation of microRNA. Furthermore, we demonstrate that gene networks constructed following medium and prolonged exposure to sAPP $\alpha$ reveal novel mechanisms likely to underpin and consolidate the neuroprotective stimulus induced by sAPPa in the hippocampus. 


\section{Methods}

\section{Organotypic hippocampal slice cultures Preparation and maintenance}

Organotypic hippocampal slice cultures were prepared from 7-10 day old Sprague Dawley rat pups of either sex according to the method of Stoppini et al., [86]. The animals were deeply anaesthetized with ketamine (100 $\mathrm{mg} / \mathrm{kg}$, i.p.), using a protocol approved by the University of Otago Animal Ethics Committee to ensure minimal animal suffering. Brains were removed and placed in ice-cold filter-sterilized dissection media consisting of Minimum Essential Medium (MEM) containing Hank's salts $(95.5 \%$, Gibco), penicillin-streptomycin solution (1\%, Gibco), HEPES buffer solution (2.5\%, Gibco) and $1 \mathrm{M}$ Tris- $\mathrm{HCl}$ (1\%, Invitrogen, CA, USA). Hippocampi were then dissected free on an ice-cold glass plate and transverse slices cut at $400 \mu \mathrm{m}$ on a Mcllwain tissue chopper (Mickle Laboratory Engineering, Surry, England). Separated slices were individually placed onto cell culture inserts (Millicell ${ }^{\circ}$, Millipore, MA, USA) held in $35 \mathrm{~mm}$ disposable petri dishes (Nunc, Denmark). To control for any gender differences, individual slices were randomised across all inserts. Slices were subsequently incubated in media containing MEM with Hank's salts (50\%), Hank's balanced salt solution (25\%, Gibco) and heat-inactivated horse serum (25\%, Gibco) with 100 units of penicillinstreptomycin/ml and buffered to $\mathrm{pH} 7.2$ with $1 \mathrm{M}$ HEPES solution for three days at $37^{\circ} \mathrm{C}$ in a humidified incubator containing $5 \% \mathrm{CO}_{2}$, and subsequently at $34^{\circ} \mathrm{C}$. Culture medium was changed after the initial $24 \mathrm{~h}$, and then every 3 days.

\section{Experimental manipulation}

Slices were allocated to experimental groups after 10-11 days in vitro (DIV). Neuroprotection assays and gene expression experiments contained slices from 4 animals, with 4-5 slices on each insert. All treatments were conducted in culture medium in which the horse serum was replaced with the same volume of MEM. Recombinant human sAPPa was produced using human embryonic kidney-293 cells in which the sAPP $\alpha$ gene fragment was stably integrated [23].

\section{Neuroprotection assay}

Organotypic hippocampal slices were pre-treated with sAPP $\alpha(0.03-10 \mathrm{nM})$ or PBS for $24 \mathrm{~h}$ before treatment with NMDA (30 $\mu \mathrm{M}, 30 \mathrm{~min})$ to induce partial, hippocampal-wide neuronal cell death. sAPP $\alpha$ was removed during the NMDA challenge, but subsequently reintroduced at the same concentration for a further $48 \mathrm{~h}$.

\section{Fluorescence imaging}

Levels of cell death were determined $48 \mathrm{~h}$ after NMDA treatment using fluorescence imaging. Dead cells were labelled using the fluorescent dye propidium iodide (PI, ex. $536 \mathrm{~nm}$, em. $617 \mathrm{~nm}$ ). Emitted fluorescence was imaged with a Zeiss Axio Scope A1 microscope fitted with an LED illumination system and fluorescence filter cube (LED module ex. 540-580 nm; Zeiss filter set 43, ex. $545 \mathrm{~nm}$ - excitation, $605 \mathrm{~nm}$-emission). Images were acquired with a Scion Corporation (Frederick, MD, USA) 12-bit colour camera (model CFW-1612C) and Scion Corporation VisiCapture image acquisition software. This software enabled us to reduce electronic and background image noise by collecting images that were the average of the previous five frames. For the purposes of analysis, each cultured slice was divided up into four principal areas CA1, CA3, inner blade of the dentate gurus (DG/ib), and outer blade of the dentate gyrus (DG/ob).

\section{Image analysis}

Cell death was quantified by measuring the average pixel intensity within a manually-selected region-of-interest (ROI) using ImageJ software (http://rsbweb.nih.gov/ij/ download.html). For each image, the cell body layer was identified and manually selected as a ROI from which the average pixel intensity was calculated. The positioning of each ROI was dependent on the area to be analysed; CA1: identified as the cell body layer immediately above the DG; CA3: identified as the layer continuous with, and extending beyond, CA1 and ending before it entered the hilus of the DG. DG: divided into inner and outer blades with an approximate mid-point selected to demarcate the segments (Figure 1). The ROI size for each of the four areas was kept consistent between images.

\section{Data analysis}

For assessment of regional sAPP $\alpha$ effects, raw PI intensity values in the SAPP $\alpha$ groups were compared across the control and NMDA group values using a 1-way ANOVA with a post-hoc Bonferroni correction. Significance was set at $p<0.05$.

\section{Transcriptome analysis}

Organotypic hippocampal slices were incubated with media containing $1 \mathrm{nM}$ sAPP $\alpha$ or PBS for $15 \mathrm{~min}, 2 \mathrm{~h}$ or $24 \mathrm{~h}(\mathrm{n}=5$ samples per treatment group, with each sample consisting of 5 randomly selected slices from 4 animals), rinsed with PBS, fixed in $70 \%(\mathrm{v} / \mathrm{v})$ ETOH and snap frozen. Total RNA was prepared from organotypic hippocampal slices following tissue grinding on dry ice and shearing through a $22 \mathrm{G} \times 1$ " Ultra Thin Wall Needle (Terumo ${ }^{\circ}$, Japan), using the NORGEN Total RNA Purification Kit (Norgen Biotek Corporation, Canada), plus DNAse I treatment step (Qiagen, Germany). RNA sample concentrations and integrity were determined using spectrophotometry (Nanodrop 1000; Thermo Scientific, USA) and a Bioanalyzer, using an RNA 6000 Nano 
Labchip (Bioanalyzer 2100; Agilent Techologies, USA). Only samples with an average RNA integrity number $>8$ were used $[87,88]$. Array hybridizations were carried out at the Otago Genomics Facility (University of Otago), where RNA samples were biotin-labeled and hybridized to Affymetrix Rat Gene 1.0 ST arrays. These arrays cover 27342 annotated genes represented by $\sim 26$ probes spread across the full-length of each gene. A subset of microRNA are represented on the Rat GeneChip. The microRNA specific probes align to the stem loop sequences with the potential to identify both the primary and precursor forms of the transcripts.

\section{Microarray data analysis}

The Robust Multichip Average (RMA) package was used to normalize the data derived from treated and control samples (Sketch expression consul, Affymetrix, USA). In order to produce an inclusive list of SAPP $\alpha$ related genes and microRNA suitable for network analysis, differentially expressed genes were identified using two selection criteria: a threshold fold change cutoff $( \pm 1.15)$ and a moderated $t$-test with a significance criterion of $p<0.05$ [29]. The t-statistic was generated using the Limma package, which utilizes a standard error moderated across all genes using a simple Bayesian model and produces $p$-values with greater degrees of freedom and hence greater reliability [89]. More stringent selection criteria were not used in this study to avoid the risk of Type 2 error and unnecessarily limit the datasets for network analysis [90,91].

To investigate potential microRNA likely to regulate the observed datasets, we used the web application miRvestigator Framework (http://mirvestigator.systemsbiology. net/) that identifies microRNA responsible for co-regulated gene expression patterns [33,92].

\section{Identification of biologically relevant networks and biological functions}

Ingenuity pathway analysis, version 9 (IPA) (Ingenuity Systems, www.ingenuity.com) was used to investigate interaction-based relationships between the genes and proteins encoded by the sAPP $\alpha$-regulated gene expression sets. The gene sets, containing Affymetrix identifiers and corresponding expression values $(p<0.05)$, were submitted for analysis and gene networks were produced. Each network contains up to 35 genes and has an associated score derived from a $p$-value, indicating the expected likelihood of the genes being present in a network compared to that expected by chance. Scores of two or above have at least a $99 \%$ likelihood of not being generated by chance.

As the use of multiple tools is highly recommended for functional analysis of microarray data [93], we also applied an alternative analysis approach, Functional
Annotation Clustering (DAVID [93]) to analyse the differentially expressed genes. In contrast to IPA, which is an interaction-based analysis, DAVID categorises the genes into groups based on Gene Ontology terms, and then displays similar annotations together. The total set of genes on the appropriate microarray was used as the background. The annotation terms are clustered based on the share of common genes and an EASE score, a modified Fisher exact p-value, is produced for each annotation term. Usually a $p$-value equal or smaller than 0.05 is considered strongly enriched in the annotation categories [93]. Next, the annotation terms were clustered based on similar annotation terms and genes. The overall enrichment score of each cluster was based on the EASE scores of each annotation term. Clusters with a minimum enrichment score of 1.3 (equivalent to a $p$-value of 0.05 ) were deemed significant.

\section{Real-time quantitative PCR}

Selected biologically relevant differentially expressed genes were analysed by quantitative PCR (qPCR). Extracted RNA was reverse-transcribed to first strand cDNA using Superscript III (Invitrogen, CA, USA). Sixteen primer pairs were designed using Primer 3 (http://primer3.wi.mit. edu/) and obtained from Integrated DNA Technologies, (USA). Primer sequences are described in Additional file 6: Table S7. qPCR was performed using SYBR green mastermix (Roche, Switzerland) on a Roche Lightcycler 480. The GPCR validation included animals from the same RNA used in the microarray analysis. Results were normalised to the housekeeping genes Hypoxanthine phosphoribosyltransferase 1 (Hprt) and Peptidylprolyl isomerase A (Ppia) using the $2^{-\Delta \Delta} \mathrm{CT}$ method [94]. These genes have consistently remained stable across numerous studies in the hippocampus eg [95,96]. Significance was assessed using Student's $t$-tests with the criterion set at $p<0.05$ and 1.2 fold change.

\section{Availability of supporting data}

The data sets supporting the results of this article will be available in the ArrayExpress repository, accession number pending.

\section{Additional files}

Additional file 1: Figure S1. Neuroprotective effects of SAPPa are concentration dependent. Change in cell death in DG/ob following treatment of sAPPa (0.03-10 nM) relative to control/NMDA treatment. *:p $<0.05, n=4$ animals, 19 slices/group. sAPPa neuroprotection followed a U-shaped dose-response curve, with increasing concentrations of SAPPa (to a maximum of $1 \mathrm{nM}$ ) leading to a significant neuroprotective effect, which then decreased with increasing concentrations of SAPPa. This agrees with our previous study [16], where we observed a dose dependent facilitation of in vivo LTP by SAPPa, with little effects on LTP at low concentrations, facilitation at mid-range concentrations and 
significant inhibition at high concentrations. This may reflect the occupancy/binding properties of the receptor of SAPPa, as yet unidentified [12,97]. No significant effects were detected following incubation with the other SAPPa + NMDA concentrations.

Additional file 2: Tables S1-S4. Significantly expressed transcripts clusters following 15 min (Table S1), 2 h (Table S2) and 24 h (Table S3) SAPPa exposure. Table S4: Validation of selected differentially expressed genes by $\mathrm{qPCR}$ including associated $p$-values. Entries without gene symbols and titles have no annotations associated with these probe ids.

Additional file 3: Table S5. Expression of SAPPa related genes across time. Overlapping temporal gene expression lists from Venn diagram (Figure 2B). NC: no change in gene expression at this time.

Additional file 4: Table S6. DAVID functional annotation clustering of SAPPa-regulated genes.

Additional file 5: Figure S2. Genes with annotations related to neurogenesis and development. Associations between the $24 \mathrm{~h}$ gene list and their annotations following DAVID functional analysis. The region in green illustrates that all annotations are common across the cluster. Enrichment score 2.35 .

Additional file 6: Table S7. List of primers used for real-time GPCR.

\section{Competing interests}

The authors declare no competing interests.

\section{Authors' contributions}

MMR and GPM were the major contributors to the experimental aspects of the study. MMR conceived and designed the study, carried out two of the experimental array studies and validations, the statistical and data analysis and interpretation, and drafted the manuscript. GPM helped design the study, carried out one array study and validation, the corresponding data analysis and interpretation, and drafted the manuscript. BGM prepared the hippocampal organotypic slice cultures, and validated the neuroprotective function of SAPPa against excitotoxicity. KB developed the laboratory-based production and purification of SAPPa in human cells. WCA contributed to the design of the study and critically revised the manuscript. WPT and JMW were equal, complementary contributors to the overall leadership of the project. WPT conceived, participated in the design and co-ordinated the experimental aspects of the study, and helped draft the manuscript. JMW conceived and participated in the design and co-ordination of the study, undertook critical data analysis and interpretation, and drafted the manuscript. All authors read and approved the final manuscript.

\section{Acknowledgements}

This study was supported by the New Zealand Health Research Council, the Royal Society of New Zealand Marsden Fund and the Neurological Foundation of New Zealand. We thank Dr. Shane Ohline and Ryan Abraham for technical assistance in producing the hippocampal organotypic slices and the neuroprotection assay, respectively. We also thank Les McNoe from the Otago Genomics Facility for assisting with the microarrays and Diane Guévremont for proofreading of the manuscript.

\section{Author details}

'Brain Health Research Centre, University of Otago, PO Box 56, Dunedin New Zealand. ${ }^{2}$ Department of Anatomy, Otago School of Medical Sciences, PO Box 913, Dunedin, New Zealand. ${ }^{3}$ Department of Biochemistry, Otago School of Medical Sciences, PO Box 56, Dunedin, New Zealand. ${ }^{4}$ Department of Psychology, University of Otago, PO Box 56, Dunedin, New Zealand. ${ }^{5}$ Neuroscience Department, Garvan Institute of Medical Research, Sydney, Australia.

Received: 14 November 2012 Accepted: 24 May 2013

Published: 6 June 2013

\section{References}

1. Villemagne VL, Perez KA, Pike KE, Kok WM, Rowe CC, White AR, Bourgeat P, Salvado O, Bedo J, Hutton CA, et al: Blood-borne amyloid-beta dimer correlates with clinical markers of Alzheimer's disease. J Neurosci 2010, 30(18):6315-6322.
2. Moghekar A, Rao S, Li M, Ruben D, Mammen A, Tang X, O'Brien RJ: Large quantities of Abeta peptide are constitutively released during amyloid precursor protein metabolism in vivo and in vitro. J Biol Chem 2011, 286(18):15989-15997.

3. Turner PR, O'Connor K, Tate WP, Abraham WC: Roles of amyloid precursor protein and its fragments in regulating neural activity, plasticity and memory. Prog Neurobiol 2003, 70(1):1-32.

4. Masters CL, Simms G, Weinman NA, Multhaup G, McDonald BL, Beyreuther K: Amyloid plaque core protein in Alzheimer disease and Down syndrome. Proc Natl Acad Sci U S A 1985, 82(12):4245-4249.

5. Obregon D, Hou H, Deng J, Giunta B, Tian J, Darlington D, Shahaduzzaman M, Zhu Y, Mori T, Mattson MP, et al: Soluble amyloid precursor proteinalpha modulates beta-secretase activity and amyloid-beta generation. Nat Commun 2012, 3:777.

6. Mattson MP, Cheng B, Culwell AR, Esch FS, Lieberburg I, Rydel RE: Evidence for excitoprotective and intraneuronal calcium-regulating roles for secreted forms of the beta-amyloid precursor protein. Neuron 1993, 10(2):243-254

7. Thornton E, Vink R, Blumbergs PC, Van Den Heuvel C: Soluble amyloid precursor protein alpha reduces neuronal injury and improves functional outcome following diffuse traumatic brain injury in rats. Brain Res 2006, 1094(1):38-46.

8. Milward EA, Papadopoulos R, Fuller SJ, Moir RD, Small D, Beyreuther K, Masters $\mathrm{CL}$ : The amyloid protein precursor of Alzheimer's disease is a mediator of the effects of nerve growth factor on neurite outgrowth. Neuron 1992, 9(1):129-137.

9. Ninomiya H, Roch JM, Jin LW, Saitoh T: Secreted form of amyloid beta/A4 protein precursor (APP) binds to two distinct APP binding sites on rat B103 neuron-like cells through two different domains, but only one site is involved in neuritotropic activity. J Neurochem 1994, 63(2):495-500

10. Baratchi S, Evans J, Tate WP, Abraham WC, Connor B: Secreted amyloid precursor proteins promote proliferation and glial differentiation of adult hippocampal neural progenitor cells. Hippocampus 2012, 22(7):1517-1527.

11. Porayette P, Gallego MJ, Kaltcheva MM, Bowen RL, Vadakkadath Meethal S, Atwood CS: Differential processing of amyloid-beta precursor protein directs human embryonic stem cell proliferation and differentiation into neuronal precursor cells. J Biol Chem 2009, 284(35):23806-23817.

12. Caille I, Allinquant B, Dupont E, Bouillot C, Langer A, Muller U, Prochiantz A: Soluble form of amyloid precursor protein regulates proliferation of progenitors in the adult subventricular zone. Development 2004, 131(9):2173-2181.

13. Bour A, Little S, Dodart JC, Kelche C, Mathis C: A secreted form of the beta-amyloid precursor protein (SAPP695) improves spatial recognition memory in OF1 mice. Neurobiol Learn Mem 2004, 81(1):27-38.

14. Ishida A, Furukawa K, Keller JN, Mattson MP: Secreted form of betaamyloid precursor protein shifts the frequency dependency for induction of LTD, and enhances LTP in hippocampal slices. NeuroReport 1997, 8(9-10):2133-2137.

15. Meziane H, Dodart JC, Mathis C, Little S, Clemens J, Paul SM, Ungerer A: Memory-enhancing effects of secreted forms of the beta-amyloid precursor protein in normal and amnestic mice. Proc Natl Acad Sci USA 1998, 95(21):12683-12688.

16. Taylor CJ, Ireland DR, Ballagh I, Bourne K, Marechal NM, Turner PR, Bilkey DK, Tate WP, Abraham WC: Endogenous secreted amyloid precursor proteinalpha regulates hippocampal NMDA receptor function, long-term potentiation and spatial memory. Neurobiol Dis 2008, 31(2):250-260.

17. Claasen AM, Guevremont D, Mason-Parker SE, Bourne K, Tate WP, Abraham WC, Williams JM: Secreted amyloid precursor protein-alpha upregulates synaptic protein synthesis by a protein kinase G-dependent mechanism. Neurosci Lett 2009, 460(1):92-96.

18. Barger SW, Mattson MP: The secreted form of the Alzheimer's $\beta$-amyloid precursor protein stimulates a membrane-associated guanylate cyclase. Biochem J 1995, 311(1):45-47.

19. Barger SW, Fiscus RR, Ruth P, Hofmann F, Mattson MP: Role of cyclic GMP in the regulation of neuronal calcium and survival by secreted forms of beta-amyloid precursor. J Neurochem 1995, 64(5):2087-2096.

20. Cheng G, Yu Z, Zhou D, Mattson MP: Phosphatidylinositol-3-kinase-Akt kinase and p42/p44 mitogen-activated protein kinases mediate neurotrophic and excitoprotective actions of a secreted form of amyloid precursor protein. Exp Neurol 2002, 175(2):407-414.

21. Gakhar-Koppole N, Hundeshagen P, Mandl C, Weyer SW, Allinquant B, Muller $\mathrm{U}$, Ciccolini F: Activity requires soluble amyloid precursor protein 
alpha to promote neurite outgrowth in neural stem cell-derived neurons via activation of the MAPK pathway. Eur J Neurosci 2008, 28(5):871-882.

22. Chasseigneaux S, Dinc L, Rose C, Chabret C, Coulpier F, Topilko P, Mauger G, Allinquant B: Secreted amyloid precursor protein beta and secreted amyloid precursor protein alpha induce axon outgrowth in vitro through Egr1 signaling pathway. PLoS One 2011, 6(1):e16301.

23. Stein TD, Anders NJ, DeCarli C, Chan SL, Mattson MP, Johnson JA: Neutralization of transthyretin reverses the neuroprotective effects of secreted amyloid precursor protein (APP) in APPSW mice resulting in tau phosphorylation and loss of hippocampal neurons: support for the amyloid hypothesis. J Neurosci 2004, 24(35):7707-7717.

24. Aydin D, Filippov MA, Tschape JA, Gretz N, Prinz M, Eils R, Brors B, Muller UC: Comparative transcriptome profiling of amyloid precursor protein family members in the adult cortex. BMC Genomics 2011, 12:160

25. Turner PR, Bourne K, Garama D, Carne A, Abraham WC, Tate WP. Production, purification and functional validation of human secreted amyloid precursor proteins for use as neuropharmacological reagents. J Neurosci Methods 2007, 164(1):68-74

26. Sinor JD, Du S, Venneti S, Blitzblau RC, Leszkiewicz DN, Rosenberg PA Aizenman E: NMDA and glutamate evoke excitotoxicity at distinct cellular locations in rat cortical neurons in vitro. J Neurosci 2000, 20(23):8831-8837.

27. Soverchia L, Ubaldi M, Leonardi-Essmann F, Ciccocioppo R, Hardiman G: Microarrays-the challenge of preparing brain tissue samples. Addict Biol 2005, 10(1):5-13.

28. Prinzen C, Trumbach D, Wurst W, Endres K, Postina R, Fahrenholz F: Differential gene expression in ADAM10 and mutant ADAM10 transgenic mice. BMC Genomics 2009, 10:66

29. Ryan MM, Mason-Parker SE, Tate WP, Abraham WC, Williams JM: Rapidly induced gene networks following induction of long-term potentiation at perforant path synapses in vivo. Hippocampus 2011, 21(5):541-553.

30. Ryan MM, Ryan B, Kyrke-Smith M, Logan B, Tate WP, Abraham WC, Williams $J M$ : Temporal profiling of gene networks associated with the late phase of long-term potentiation in vivo. PLOS One 2012, 7(7):e40538.

31. Tian L, McClafferty H, Knaus HG, Ruth P, Shipston MJ: Distinct acyl protein transferases and thioesterases control surface expression of calciumactivated potassium channels. J Biol Chem 2012, 287(18):14718-14725.

32. Fukata Y, Fukata M: Protein palmitoylation in neuronal development and synaptic plasticity. Nat Rev Neurosci 2010, 11(3):161-175.

33. Bartel DP: MicroRNAs: target recognition and regulatory functions. Cell 2009, 136(2):215-233.

34. Di Bona D, Candore G, Franceschi C, Licastro F, Colonna-Romano G, Camma C, Lio D, Caruso C: Systematic review by meta-analyses on the possible role of TNF-alpha polymorphisms in association with Alzheimer's disease. Brain Res Rev 2009, 61(2):60-68.

35. Malinin NL, Wright S, Seubert P, Schenk D, Griswold-Prenner I: Amyloidbeta neurotoxicity is mediated by FISH adapter protein and ADAM12 metalloprotease activity. Proc Natl Acad Sci U S A 2005, 102(8):3058-3063.

36. Le Y, Gong W, Tiffany HL, Tumanov A, Nedospasov S, Shen W, Dunlop NM, Gao JL, Murphy PM, Oppenheim JJ, et al: Amyloid (beta)42 activates a G-protein-coupled chemoattractant receptor, FPR-like-1. J Neurosci 2001 21(2):RC123.

37. Butterfield DA, Hardas SS, Lange ML: Oxidatively modified glyceraldehyde3-phosphate dehydrogenase (GAPDH) and Alzheimer's disease: many pathways to neurodegeneration. J Alzheimers Dis 2010, 20(2):369-393.

38. Du H, Guo L, Fang F, Chen D, Sosunov AA, McKhann GM, Yan Y, Wang C, Zhang $H$, Molkentin JD, et al: Cyclophilin D deficiency attenuates mitochondrial and neuronal perturbation and ameliorates learning and memory in Alzheimer's disease. Nat Med 2008, 14(10):1097-1105.

39. Barger SW, Horster D, Furukawa K, Goodman Y, Krieglstein J, Mattson MP. Tumor necrosis factors alpha and beta protect neurons against amyloid beta-peptide toxicity: evidence for involvement of a kappa B-binding factor and attenuation of peroxide and $\mathrm{Ca} 2+$ accumulation. Proc Nat Acad Sci U S A 1995, 92(20):9328-9332.

40. Schwarzman AL, Gregori L, Vitek MP, Lyubski S, Strittmatter WJ, Enghilde JJ, Bhasin R, Silverman J, Weisgraber KH, Coyle PK, et al: Transthyretin sequesters amyloid beta protein and prevents amyloid formation. Proc Natl Acad Sci U S A 1994, 91(18):8368-8372.

41. Liao Y, Guan ZZ, Ravid R: [Changes of nuclear factor and inflammatory chemotactic factors in brain of patients with Alzheimer's disease]. Zhonghua Bing Li Xue Za Zhi 2011, 40(9):585-589.
42. Lu W, Mi R, Tang H, Liu S, Fan M, Wang L: Over-expression of c-fos mRNA in the hippocampal neurons in Alzheimer's disease. Chin Med J (Engl) 1998, 111(1):35-37.

43. Blum-Degen D, Muller T, Kuhn W, Gerlach M, Przuntek H, Riederer P: Interleukin- 1 beta and interleukin- 6 are elevated in the cerebrospinal fluid of Alzheimer's and de novo Parkinson's disease patients. Neurosci Lett 1995, 202(1-2):17-20.

44. Lukiw WJ: Micro-RNA speciation in fetal, adult and Alzheimer's disease hippocampus. NeuroReport 2007, 18(3):297-300.

45. Hebert SS, Horre K, Nicolai L, Papadopoulou AS, Mandemakers W, Silahtaroglu AN, Kauppinen S, Delacourte A, De Strooper B: Loss of microRNA cluster miR-29a/b-1 in sporadic Alzheimer's disease correlates with increased BACE1/beta-secretase expression. Proc Natl Acad Sci USA 2008, 105(17):6415-6420

46. Bensemain F, Hot D, Ferreira S, Dumont J, Bombois S, Maurage CA, Huot L, Hermant X, Levillain E, Hubans C, et al: Evidence for induction of the ornithine transcarbamylase expression in Alzheimer's disease. Mol Psychiatry 2009, 14(1):106-116.

47. Liu F, Arias-Vasquez A, Sleegers K, Aulchenko YS, Kayser M, Sanchez-Juan P, Feng BJ, Bertoli-Avella AM, van Swieten J, Axenovich TI, et al: A genomewide screen for late-onset Alzheimer disease in a genetically isolated Dutch population. Am J Hum Genet 2007, 81(1):17-31.

48. Pérez-Cadahía B, Drobic B, Davie JR: Activation and function of immediate-early genes in the nervous system. Biochem Cell Biol 2011, 89(1):61-73.

49. Chinenov Y, Kerppola TK: Close encounters of many kinds: Fos-Jun interactions that mediate transcription regulatory specificity. Oncogene 2001, 20(19):2438-2452.

50. Tulchinsky E: Fos family members: regulation, structure and role in oncogenic transformation. Histol Histopathol 2000, 15(3):921-928.

51. Song HY, Regnier $C H$, Kirschning CJ, Goeddel DV, Rothe M: Tumor necrosis factor (TNF)-mediated kinase cascades: bifurcation of nuclear factor-kappaB and c-jun N-terminal kinase (JNK/SAPK) pathways at TNF receptorassociated factor 2. Proc Natl Acad Sci U S A 1997, 94(18):9792-9796.

52. Huang EJ, Reichardt LF: Neurotrophins: roles in neuronal development and function. Annu Rev Neurosci 2001, 24:677-736.

53. Camporeale G, Oommen AM, Griffin JB, Sarath G, Zempleni J: K12-biotinylated histone $\mathrm{H} 4$ marks heterochromatin in human lymphoblastoma cells. J Nutr Biochem 2007, 18(11):760-768.

54. Bao B, Pestinger V, Hassan Yl, Borgstahl GE, Kolar C, Zempleni J: Holocarboxylase synthetase is a chromatin protein and interacts directly with histone $\mathrm{H} 3$ to mediate biotinylation of $\mathrm{K} 9$ and K18. J Nutr Biochem 2011, 22(5):470-475.

55. Roozendaal B, Phillips RG, Power AE, Brooke SM, Sapolsky RM, McGaugh JL: Memory retrieval impairment induced by hippocampal CA3 lesions is blocked by adrenocortical suppression. Nat Neurosci 2001, 4(12):1169-1171.

56. Kulstad JJ, McMillan PJ, Leverenz JB, Cook DG, Green PS, Peskind ER, Wilkinson CW, Farris W, Mehta PD, Craft S: Effects of chronic glucocorticoid administration on insulin-degrading enzyme and amyloid-beta peptide in the aged macaque. J Neuropathol Exp Neurol 2005, 64(2):139-146.

57. Griffin W, Stanley L, Ling C, White L, MacLeod V, Perrot L, White C, Araoz C: Brain interleukin 1 and S-100 immunoreactivity are elevated in Down syndrome and Alzheimer disease. Proc Natl Acad Sci U S A 1989, 86(19):7611-7615.

58. Carter C: Convergence of genes implicated in Alzheimer's disease on the cerebral cholesterol shuttle: APP, cholesterol, lipoproteins, and atherosclerosis. Neurochem Int 2007, 50(1):12-38.

59. Dinarello C: Biologic basis for interleukin-1 in disease. Blood 1996 87(6):2095-2147.

60. Politis A, Olgiati P, Malitas P, Albani D, Signorini A, Polito L, De Mauro S, Zisaki A, Piperi C, Stamouli E, et al: Vitamin B12 levels in Alzheimer's disease: association with clinical features and cytokine production. J Alzheimers Dis 2010, 19(2):481-488

61. Spulber S, Bartfai T, Schultzberg M: IL-1/IL-1ra balance in the brain revisited - evidence from transgenic mouse models. Brain Behav Immun 2009, 23(5):573-579.

62. Bajetto A, Bonavia R, Barbero S, Schettini G: Characterization of chemokines and their receptors in the central nervous system: physiopathological implications. J Neurochem 2002, 82(6):1311-1329. 
63. Cartier L, Hartley O, Dubois-Dauphin M, Krause KH: Chemokine receptors in the central nervous system: role in brain inflammation and neurodegenerative diseases. Brain Res Brain Res Rev 2005, 48(1):16-42.

64. Fujikawa M, Katagiri T, Tugores A, Nakamura Y, Ishikawa F: ESE-3, an Ets family transcription factor, is up-regulated in cellular senescence. Cancer Sci 2007, 98(9):1468-1475.

65. Dezor M, Dorszewska J, Florczak J, Kempisty B, Jaroszewska-Kolecka J, Rozycka A, Polrolniczak A, Bugaj R, Jagodzinski PP, Kozubski W: Expression of 8-oxoguanine DNA glycosylase 1 (OGG1) and the level of p53 and TNF-alphalpha proteins in peripheral lymphocytes of patients with Alzheimer's disease. Folia Neuropathol 2011, 49(2):123-131.

66. de la Monte SM, Wands JR: Molecular indices of oxidative stress and mitochondrial dysfunction occur early and often progress with severity of Alzheimer's disease. J Alzheimers Dis 2006, 9(2):167-181.

67. Smith-Swintosky VL, Pettigrew LC, Craddock SD, Culwell AR, Rydel RE, Mattson MP: Secreted forms of beta-amyloid precursor protein protect against ischemic brain injury. J Neurochem 1994, 63(2):781-784.

68. Araki W, Kitaguchi N, Tokushima Y, Ishii K, Aratake H, Shimohama S, Nakamura S, Kimura J: Trophic effect of beta-amyloid precursor protein on cerebral cortical neurons in culture. Biochem Biophys Res Commun 1991, 181(1):265-271.

69. Walsh DM, Selkoe DJ: Deciphering the Molecular Basis of Memory Failure in Alzheimer's Disease. Neuron 2004, 44(1):181-193.

70. Barger SW, Mattson MP: Participation of gene expression in the protection against amyloid beta-peptide toxicity by the beta-amyloid precursor protein. Ann N Y Acad Sci 1996, 777:303-309.

71. Barger SW, Mattson MP: Induction of neuroprotective kappa B-dependent transcription by secreted forms of the Alzheimer's beta-amyloid precursor. Brain Res Mol Brain Res 1996, 40(1):116-126.

72. Guo Q, Robinson N, Mattson MP: Secreted beta-amyloid precursor protein counteracts the proapoptotic action of mutant presenilin- 1 by activation of NF-kappaB and stabilization of calcium homeostasis. J Biol Chem 1998, 273(20):12341-12351.

73. Bonizzi G, Karin M: The two NF-kappaB activation pathways and their role in innate and adaptive immunity. Trends Immunol 2004, 25(6):280-288.

74. Chami L, Buggia-Prevot V, Duplan E, Delprete D, Chami M, Peyron JF, Checler F: Nuclear Factor-kappaB Regulates betaAPP and beta- and gamma-Secretases Differently at Physiological and Supraphysiological Abeta Concentrations. J Biol Chem 2012, 287(29):24573-24584.

75. Cogswell JP, Ward J, Taylor IA, Waters M, Shi Y, Cannon B, Kelnar K, Kemppainen J, Brown D, Chen C, et al: Identification of miRNA changes in Alzheimer's disease brain and CSF yields putative biomarkers and insights into disease pathways. J Alzheimers Dis 2008, 14(1):27-41.

76. Lukiw WJ, Zhao Y, Cui JG: An NF-kappaB-sensitive micro RNA-146a -mediated inflammatory circuit in Alzheimer disease and in stressed human brain cells. J Biol Chem 2008, 283(46):31315-31322.

77. Routtenberg A, Rekart JL: Post-translational protein modification as the substrate for long-lasting memory. Trends Neurosci 2005, 28(1):12-19.

78. Sacktor TC: How does PKMzeta maintain long-term memory? Nat Rev Neurosci 2011, 12(1):9-15

79. Maccecchini ML, Chang MY, Pan C, John V, Zetterberg H, Greig NH: Posiphen as a candidate drug to lower CSF amyloid precursor protein, amyloid-beta peptide and tau levels: target engagement, tolerability and pharmacokinetics in humans. J Neurol Neurosurg Psychiatry 2012, 83(9):894-902

80. Olsson A, Hoglund K, Sjogren M, Andreasen N, Minthon L, Lannfelt L, Buerger K, Moller HJ, Hampel H, Davidsson P, et al: Measurement of alphaand beta-secretase cleaved amyloid precursor protein in cerebrospinal fluid from Alzheimer patients. Exp Neurol 2003, 183(1):74-80.

81. Wu G, Sankaranarayanan S, Hsieh SH, Simon AJ, Savage MJ: Decrease in brain soluble amyloid precursor protein beta (sAPPbeta) in Alzheimer's disease cortex. J Neurosci Res 2011, 89(6):822-832.

82. Freude KK, Penjwini M, Davis JL, Laferla FM, Blurton-Jones M: Soluble amyloid precursor protein induces rapid neural differentiation of human embryonic stem cells. J Biol Chem 2011, 286(27):24264-24274.

83. Laplagne DA, Esposito MS, Piatti VC, Morgenstern NA, Zhao C, van Praag H, Gage FH, Schinder AF: Functional convergence of neurons generated in the developing and adult hippocampus. PLOS Biol 2006, 4(12):e409.

84. Dhandapani KM, Hadman M, De Sevilla L, Wade MF, Mahesh VB, Brann DW: Astrocyte protection of neurons: role of transforming growth factor-beta signaling via a c-Jun-AP-1 protective pathway. J Biol Chem 2003, 278(44):43329-43339.

85. Kamphuis W, Dijk F, van Soest S, Bergen AA: Global gene expression profiling of ischemic preconditioning in the rat retina. Mol Vis 2007, 13:1020-1030

86. Stoppini L, Buchs PA, Muller D: A simple method for organotypic cultures of nervous tissue. J Neurosci Methods 1991, 37(2):173-182.

87. Schroeder A, Mueller O, Stocker S, Salowsky R, Leiber M, Gassmann M Lightfoot S, Menzel W, Granzow M, Ragg T: The RIN: an RNA integrity number for assigning integrity values to RNA measurements. BMC Mol Biol 2006, 7:3.

88. Copois V, Bibeau F, Bascoul-Mollevi C, Salvetat N, Chalbos P, Bareil C, Candeil L, Fraslon C, Conseiller E, Granci V, et al: Impact of RNA degradation on gene expression profiles: assessment of different methods to reliably determine RNA quality. J Biotechnol 2007, 127(4):549-559.

89. Smyth GK: Linear models and empirical bayes methods for assessing differential expression in microarray experiments. Stat App/ Genet Mol Biol 2004, 3:Article3.

90. Dalman MR, Deeter A, Nimishakavi G, Duan ZH: Fold change and p-value cutoffs significantly alter microarray interpretations. BMC Bioinforma 2012, 13(Suppl 2):S11.

91. van Iterson $\mathrm{M}$, Boer JM, Menezes RX: Filtering. FDR and power. BMC Bioinforma 2010, 11:450

92. Plaisier CL, Bare JC, Baliga NS: miRvestigator: web application to identify miRNAs responsible for co-regulated gene expression patterns discovered through transcriptome profiling. Nucleic Acids Res 2011, 39(Web Server issue):W125-W131.

93. da Huang W, Sherman BT, Lempicki RA: Systematic and integrative analysis of large gene lists using DAVID bioinformatics resources. Nat Protoc 2009, 4(1):44-57.

94. Winer J, Jung CK, Shackel I, Williams PM: Development and validation of real-time quantitative reverse transcriptase-polymerase chain reaction for monitoring gene expression in cardiac myocytes in vitro. Anal Biochem 1999, 270(1):41-49.

95. Pernot F, Dorandeu F, Beaup C, Peinnequin A: Selection of reference genes for real-time quantitative reverse transcription-polymerase chain reaction in hippocampal structure in a murine model of temporal lobe epilepsy with focal seizures. J Neurosci Res 2010, 88(5):1000-1008.

96. Santos AR, Duarte CB: Validation of internal control genes for expression studies: effects of the neurotrophin BDNF on hippocampal neurons. J Neurosci Res 2008, 86(16):3684-3692.

97. Hoffmann J, Pietrzik CU, Kummer MP, Twiesselmann C, Bauer C, Herzog V: Binding and selective detection of the secretory $\mathrm{N}$-terminal domain of the alzheimer amyloid precursor protein on cell surfaces. J Histochem Cytochem 1999, 47(3):373-382.

doi:10.1186/1471-2164-14-376

Cite this article as: Ryan et al:: Time-dependent changes in gene expression induced by secreted amyloid precursor protein-alpha in the rat hippocampus. BMC Genomics 2013 14:376.

\section{Submit your next manuscript to BioMed Central and take full advantage of:}

- Convenient online submission

- Thorough peer review

- No space constraints or color figure charges

- Immediate publication on acceptance

- Inclusion in PubMed, CAS, Scopus and Google Scholar

- Research which is freely available for redistribution 